'Arctic Wilderness' is an interesting, refreshing, and enjoyable book, especially to those readers who, like Bob Marshall, thrill at "simply the joy of triumphing over something which is difficult to accomplish" and "setting foot where no human being has ever trod before."

George Gryc

\section{NORTHERN TREASURY.}

SELECTIONS FROM THE BEAVER

Edited by Cuffrord WILson. Toronto:

T. Nelson and Sons, 1955. $8 \frac{3}{4} x 5$ inches; riii +238 pages; plates; maps. $\$ 3.50$.

Most readers of Arctic are probably quite familiar with the magazine $T$ be Beaver, published by the Hudson's Bay Company, and will, therefore, welcome this anthology of favourite articles. The editor of The Beaver, Clifford Wilson, has selected a cross-section of articles from as far back as 1933, and has tried to retain the variety usually found in each issue. Those who do not possess the early issues of The Beaver will find this compilation interesting and entertaining.

Readers will be amused again by the light comedy of Stephen Leacock, James McCook, and Eric Nicol; they can read of arctic adventure as told by Martin Bovey, Captain Mack, and Jimmy Bell. There is early history in the accounts of Douglas Mackay, R. C. Wallace, and Mrs. Hewlett; and not forgotten are the people of the north-the Indian and Eskimo, as described by Alfred Copland, Axel Neilsen, and Bishop Marsh.

A total of twenty-four articles has been assembled in this volume, for which a short introduction was written by Leonard Brockington. The general reader will find the book entertaining, and the arctic specialist will find relaxation in the easy writing concerning his favourite region, the Northland.

J. Lewis Robinson

\title{
INSTITUTE NEWS
}

\section{Applications for the position of Executive Director}

The Board of Governors invites applications for the post of Executive Director of the Arctic Institute, which position has been held by Mr. T. $H$. Manning on a part-time, temporary basis for the past year and a half. Mr. Manning wishes to relinquish this position not later than October 31. The new appointment will be on a full-time basis at a salary commensurate with the applicant's qualifications. The Executive Director will be required to live in eastern Canada.

Applications should be addressed to the Director of the Montreal Office.

\section{'Arctic bibliography', Volume 6}

The sixth volume of 'Arctic bibliography' was published by the U.S. Government Printing Office in April 1956. Like the preceding five volumes it was edited by Miss Marie Tremaine, and prepared by the Arctic Institute for the U.S. Department of Defense. A Directing Committee, of which Dr. Henry B. Collins is the chairman, exercised general supervision.

Volume 6 lists and describes the contents of 5,285 English and foreign language publications in all fields of science relating to the arctic and subarctic regions of America and Eurasia. Subjects emphasized are geology and mineral resources; geography; zoology; medicine and physiology, especially the effects of low temperatures; engineering (navigation, aeronautics, construction, transportation); agriculture and forestry; meteorology; oceanography; anthropology and sociology; and exploration, especially Russian expansion in the north Pacific. Language coverage is similar to the earlier volumes, 3,225 of the publications listed are in English, 1,215 in Russian, 